\title{
Spatial and temporal variations of fish assemblages in a shallow Mediterranean soft- bottom area (Gulf of Fos, France)
}

\author{
Yves LETOURNEUR ${ }^{a *}$, Audrey DARNAUDE ${ }^{b}$, Chantal SALEN-PICARD ${ }^{b}$, Mireille HARMELIN-VIVIEN ${ }^{b}$ \\ a UMR CNRS 6540, Centre d'océanologie de Marseille, Case 901, Faculté des sciences de Luminy, Université \\ de la Méditerranée, 13288 Marseille cedex 09, France \\ ${ }^{\mathrm{b}}$ UMR CNRS 6540, Station marine d'Endoume, Centre d'Océanologie de Marseille, Université de la \\ Méditerranée, rue de la Batterie-des-lions, 13007 Marseille, France
}

Received 14 December 2000; revised 2 February 2001; accepted 3 February 2001

\begin{abstract}
The fish assemblages of two shallow soft-bottom areas located in the Gulf of Fos (NW Mediterranean) were studied by means of 57 trawl surveys carried out on both seasonal and diel scales between 1983 and 1985. A total of 47 fish species was recorded, with a mean density and biomass of 650 individuals ha ${ }^{-1}$ and $2.67 \mathrm{~kg} \mathrm{ha}^{-1}$, respectively. Most of the fluctuations observed were on the spatial scale. Strong differences in fish assemblages were observed between the two areas, with both higher species richness and biomass in the outer part of the gulf (La Gracieuse), while a higher density of individuals characterised its inner part (Bay of Carteau). This spatial pattern was due to a small number of species, such as the gobiids Gobius niger and Pomatoschitus minutus in Carteau, and the flatfish Arnoglossus laterna, Buglossidium luteum and Solea solea in La Gracieuse. These differences were probably induced by differences in the hydrological and benthic characteristics of the two study areas. Decreases in species richness, density and/or biomass were observed in both areas over the study period, although this trend was not significant in all cases. These decreases may have been linked to interannual variations in the mean flow rate of the Rhône River $(-28.1 \%$ between 1983 and 1985), which might have induced a decrease in the density of benthic invertebrate populations. We suggest that a similar reaction occurred in fish populations, as most of them are known to feed on these invertebrates. Diel patterns did not reveal any significant trends. However, an increase in density and biomass at sunset, and a decrease before sunrise were observed in summer in both areas, and the presence of certain specific species was recorded in catches at determined hours of the diel cycle. These observations were likely due to the activity cycles (diurnal vs. nocturnal) of the fish species. (C) 2001 Ifremer/CNRS/IRD/Éditions scientifiques et médicales Elsevier SAS
\end{abstract}

demersal ichthyofauna / Gobiidae / Pleuronectiforms / spatial distribution / temporal variations

Résumé - Variations spatio-temporelles des assemblages de poissons dans des petits fonds meubles de Méditerranée (golfe de Fos, France). Les communautés de poissons des fonds meubles de deux secteurs du golfe de Fos ont été étudiées par 57 chalutages, réalisés en différentes saisons et à différentes heures du nycthémère, entre 1983 et 1985. Un total de 47 espèces de poissons a été recensé, avec une densité et une biomasse moyennes de 650 individus ha ${ }^{-1}$ et $2,67 \mathrm{~kg} \mathrm{ha}^{-1}$, respectivement. L'essentiel des différences observées est lié à la distribution spatiale des espèces, avec une forte distinction entre les deux secteurs: la richesse spécifique et la biomasse ont été plus fortes à l'extérieur du golfe (La Gracieuse), alors que la densité a été plus forte à l'intérieur (baie de Carteau). Cette ségrégation

*Correspondence and reprints: fax: +33 491411265.

E-mail address: letourneur@com.univ-mrs.fr (Y. LETOURNEUR).

(C) 2001 Ifremer/CNRS/IRD/Éditions scientifiques et médicales Elsevier SAS. Tous droits réservés 
est surtout due à un petit nombre d'espèces, comme les Gobiidae Gobius niger et Pomatoschitus minutus, surtout capturés à Carteau, et les poissons plats Arnoglossus laterna, Buglossidium luteum et Solea solea à La Gracieuse. Ces différences sont probablement liées aux caractéristiques hydrologiques et benthiques de ces secteurs. Au cours de la période d'étude, la richesse spécifique, la densité et/ou la biomasse ont diminué sur les deux secteurs. Les variations interannuelles du débit du Rhône (-28,1\% entre 1983 et 1985) peuvent avoir induit une diminution de la densité des populations d'invertébrés benthiques. Cela aurait eu des conséquences semblables sur les poissons car la plupart d'entre eux se nourrissent de ces invertébrés. Aucune tendance particulière n'est clairement apparue au cours du nycthémère. Cependant, la densité et la biomasse ont augmenté durant la saison estivale et sur les deux secteurs, au moment du crépuscule, et ont diminué à l'aube. De plus, certaines espèces ont été capturées préférentiellement à des heures bien déterminées du nycthémère. Ces observations sont à relier aux rythmes d'activités (diurnes vs. nocturnes) des poissons qui habitent ces petits fonds sableux. (C) 2001 Ifremer/CNRS/IRD/Éditions scientifiques et médicales Elsevier SAS

\section{ichtyofaune démersale / Gobiidae / Pleuronectiformes / distribution spatiale / variations temporelles}

\section{INTRODUCTION}

Soft-bottom areas are relatively well studied on a worldwide scale, because they host large populations of commercial fish, are suitable areas for trawling, and generally support intensive fishing activity Eujita_et al. 1995. Gaertner et al. 1998. 1999: Garcia et al. 1998: Pipitone et al. 2000. Trawling affects fish assemblages in two main ways. First, fishing activities have obvious effects on targeted fish populations by reducing specimen density and size, and they also affect both associated noncommercial species and juveniles of numerous fish species Wantiez et al. 1996. Second, habitat characteristics are often strongly modified, due to the disappearance of associated benthic organisms and the homogenisation of bottom rugosity and composition Jennings and_Kaiser 1998: Frid et al.. 1999).

For these reasons, the extensive work done on softbottom areas has been 'fishing-oriented' towards a limited number of species of commercial interest, while, surprisingly, very little is known about the fish communities that inhabit such areas, either in terms of their spatial distribution or with regards to variations over time. The lack of this type of data is probably one of the major causes of the difficulties encountered in fisheries management and ecosystem conservation Botsford et al. 1997: Pauly et al. 1998: Pipitone et al. 2000).

As a result, studies focusing on the organization and functioning of soft-bottom fish communities have increasingly appeared as a necessary complement to the work already done on those biotopes, particularly for shallow water areas, which serve as nursery grounds for numerous fish species of commercial interest Warburton and Blaber. 1992: Wantiez. 1994: Wantiez et al. 1996: Dulcic et al. 1997: Lagardère at al. 1999; van der Veen and Witte, 1999: Wagner and Austin. 1999)

Few studies have been done on fish assemblages in soft-bottom areas in the NW Mediterranean. Available data focused mainly on commercial fish from the continental shelf ( 50 to $500 \mathrm{~m}$ ) at large spatial scales Gaerther. 1997: Gaertner et al. 1998. 1999) or on the local effects of fishing restrictions, such as in Sicily at depths of between 10 and $200 \mathrm{~m}$ CArena and Bombace, 1970. Arculeo et al, 1988, 1990; Pipitone et al, 2000), while studies focusing on shallow fish assemblage structures and/or functioning have been rare Ramos-Espla and Pérez-Ruzafa, 1985; Reina-Hervas and Serrano, 1987). We conducted a study of a shallow soft-bottom zone, the Gulf of Fos, located in the vicinity of significant freshwater inputs from the Rhône River, and whose fish communities have never been studied from a structural or functional point of view. Available work on that area only focused on particular aspects of the biology of a limited number of species, such as a dietary study of certain demersal fish species (Reys, 1960) a study on the recruitment patterns and processes of Solea solea $\mathrm{Le}$ Direac'h-Boursier, 1990) and a study on the spatio-temporal use of prey by four flatfish species Darnaude et al. 2001]. The present study is therefore a first step towards understanding the structure and functioning of the fish assemblages as a whole in the Gulf of Fos, and was conducted in order to respond to the following main questions: 1) do fish assemblages from two separate areas of the Gulf of Fos show significant spatial differences in their main descriptors, e.g. species richness, density and biomass? and 2) do these assemblages vary according to clearly defined diel and seasonal patterns? 


\section{MATERIALS AND METHODS}

\subsection{Study area}

This work was carried out in the Gulf of Fos (France), a shallow semi-enclosed soft-bottom zone located near the delta of the Rhône River, in the northwestern Mediterranean Sea, near the desalted de Berre Lagoon (figure 7 ). The zone studied is then subject to significant freshwater inputs, associated with a high transport of terrestrial materials. Both the de Berre Lagoon and the area surrounding the Rhône River delta were characterized by the presence of numerous factories and refineries. Two different areas were studied. The first (Carteau), located in the inner part of the Gulf of Fos, is a small bay subject to moderate hydrodynamic conditions, althought frequent northwestern trade winds generate swirling surface water movements Roux and Vernier. 1975) Temperature differences between winter and summer were significant, due to the combined effect of winds, a shallow depth, and freshwater inputs [Folack, 1986). The second area studied (La Gracieuse) is located in the outer part of the gulf, and is usually subject to high wave action and freshwater inputs, which often induce an eutrophication phenomenon (Blanc et al. 1969). The mixing of fresh and salt waters is not homogeneous in space and time, and generates sharp gradients in temperature and salinity Blanc et al. 1969) Since 1985, the area of Carteau has been occupied by large-scale permanent structures for intensive mussel aquaculture (Mytilus galloprovencialis), and is, therefore, no longer available to trawling.

\subsection{Sampling techniques}

The soft-bottom fish assemblages were sampled using a small beam-trawl as this fishing gear is best adapted to this biotope when turbidity or depth excludes the use of visual censuses Saville, 1978; Wantiez et al. 1996). The opening of the beam-trawl used was $1.5 \times 0.5 \mathrm{~m}$, with a $8 \mathrm{~mm}$ net mesh size (Harmelin-Vivien, 1981). Samples were collected after $30 \mathrm{~min}$ of trawling (mean speed: 2 knots) at La Gracieuse, and after 15 min in the Bay of Carteau due to technical restrictions in that area. The surface areas sampled were, then, $2778 \mathrm{~m}^{2}$ and $1389 \mathrm{~m}^{2}$, respectively, at depths of 5-8 $\mathrm{m}$.

The Bay of Carteau was sampled during the summers of 1983 and 1984, the winter of 1984 and the spring of 1985, whereas La Gracieuse was studied during the summer of 1984, the winter of 1984 and the summer of 1985. During each season, trawlings were carried out at $2-3 \mathrm{~h}$ intervals over a $24 \mathrm{~h}$ cycle (table $)$, according to the difference in timing for sunset and sunrise periods between these seasons. After sampling, fish were indentified, their total $(T L)$ and standard $(S L)$ lengths measured to the nearest millimetre, along with their wet weights to the nearest gram.

\subsection{Data analyses}

A correspondence analysis (CA) was applied to the global density data set, pooling all trawling from different hours and seasons. Rare species, e.g. those caught only during a single trawl, were not considered. Rare species constituted a low percentage of the whole assemblage in terms of density, but not in terms of species richness and biomass (table 1 ). The CA was thus applied to the global density data set, in order to minimize the loss of information. Examination of the absolute contributions of the species to the first factorial plan of the CA allowed the determination of the most representative species of the pattern found. The heterogeneity of dispersion was tested with random permutations of stations (trawling) between groups (seasons) (Romesburg, 1985).

The data met Levene's test criteria (homogeneity of variances) and showed a normal distribution (Kolmogorov-Smirnov test) (Sokal_and Rohlf, 1981). Two-way analyses of variance (Anova) (area $\times$ season) were then applied to compare the different data sets in terms of species richness, density and biomass. A posteriori comparisons of means were performed using the StudentNeumann-Keuls (SNK) test. Diel patterns were analysed using a chronological clustering method, where clusters were established from matrices of similarity obtained with the Steinhaus coefficient Legendre et_al__ 1985. This technique is well adapted to temporal patterns because it avoids autocorrelations between adjacent samples in the time series, such as between hours $H-1$ and $H, H$ and $H+1$, etc. in our case. A temporal contiguity constraint was applied to clusters, to determine nonoverlapping groups of samples adjacent in the time series ( $\alpha=0.05$ ). A posteriori group expansion tests were run to determine if the groups formed by the cluster were clearly separate, or if a gradual succession existed Legendre et al. 1985) 


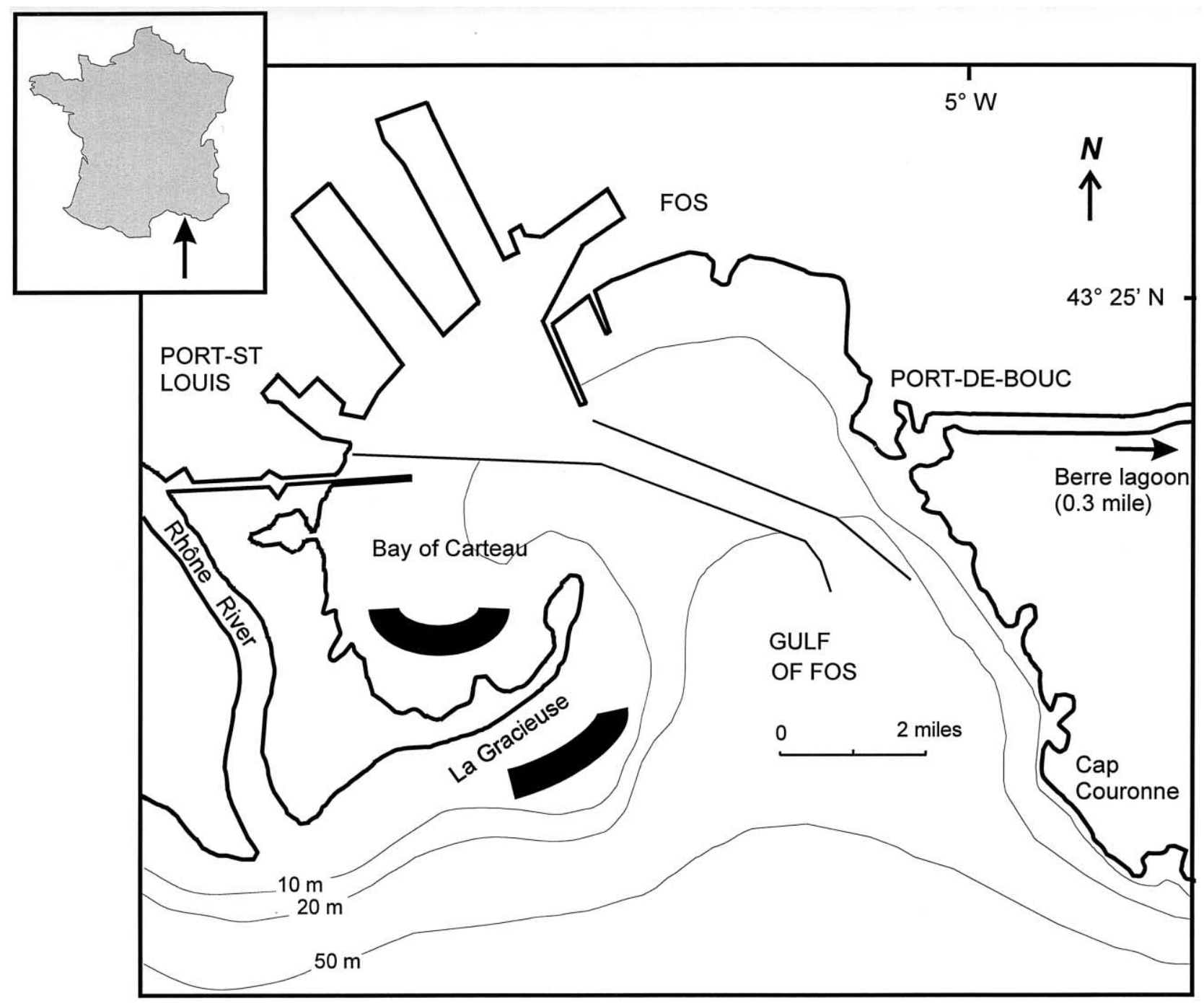

Figure 1. Location of the trawled areas (in black) in the Gulf of Fos, France (NW Mediterranean).

Table I. Hours of trawling at different seasons in the areas of Carteau and La Gracieuse.

\begin{tabular}{lll}
\hline Site & Season & Hours \\
\hline Carteau & Summer 1983 & $11: 30,14: 00,16: 00,18: 30,22: 00,00: 00,03: 00,06: 30,09: 00$ \\
& Winter 1984 & $11: 30,14: 30,17: 30,21: 30,00: 00,05: 00$ \\
& Summer 1984 & $11: 00,16: 00,20: 00,21: 30,00: 00,03: 00,06: 00$ \\
& Spring 1985 & $10: 00,11: 00,14: 00,15: 00,17: 30,21: 30,23: 00,05: 00,06: 00$ \\
La Gracieuse & Summer 1984 & $10: 00,13: 00,16: 00,20: 00,23: 00,02: 00,04: 00,07: 00,09: 00$ \\
& Winter 1985 & $10: 00,13: 00,15: 00,18: 00,23: 00,02: 30,04: 30,07: 00$ \\
& Summer 1985 & $09: 30,12: 00,16: 00,19: 00,23: 00,02: 00,04: 00,06: 00,09: 00$ \\
\hline
\end{tabular}


Table II. Importance of rare species.

\begin{tabular}{llll}
\hline & Bay of Carteau & La Gracieuse & Total \\
\hline Species richness (number of species) & $7(18.9)$ & $5(16.7)$ & $12(25.5)$ \\
Density $\left(\right.$ individuals ha $\left.^{-1}\right)$ & $25.3(3.0)$ & $8.0(2.0)$ & $17.9(2.8)$ \\
Biomass $\left(\mathrm{g} \mathrm{ha}^{-1}\right)$ & $732(39.1)$ & $486(13.1)$ & $609(21.8)$ \\
\hline
\end{tabular}

Values in brackets indicate the percentage of fish communities represented by these rare species.

\section{RESULTS}

\subsection{Fish assemblage structure}

A total of 47 fish species, belonging to 25 families, was recorded during this study, with a mean density of 650 individuals $\mathrm{ha}^{-1}$ and a mean biomass of about $2.7 \mathrm{~kg} \mathrm{ha}^{-1}$ (table $\mathrm{IW}$ ). However, fish assemblages varied significantly between the two areas, which had been characterized by there different sets of data, i.e. mean species richness, density and biomass (table $\mathrm{IW}$ ). The mean species richness and biomass per census were significantly higher (table ID and post hoc SNK tests) at La Gracieuse than at Carteau, whereas the opposite was true for mean density (table ID and post hoc SNK test). The CA revealed striking differences in fish assemblages (figure 2d). The random permutations test was highly significant $(P<0.0001)$, and demonstrated that fish as- semblages were significantly different according to area and season. Axes 1 and 2 explained $54.7 \%$ of the total inertia. Axis 1 separated the trawlings at La Gracieuse from those at Carteau. Axis 2 separated the different temporal data sets, but with different seasonal trends according to the area (foure 2d). At La Gracieuse, all summer data were grouped and were quite distinct from winter data. For Carteau, the data from summer and winter 1984 were similar and were opposed to the data from summer 1983; the data of spring 1985 were intermediate between the other two sets.

The pattern observed in the CA was mainly due to four species figure 2b.2d). The gobiid Gobius niger was strongly associated with Carteau during both summer and winter 1984, the gobiid Pomatoschistus minutus was associated with the other two seasons in Carteau, whereas the flatfish Arnoglossus laterna and Buglossidium luteum characterized the La Gracieuse area (figure 2b.d).

Table III. Total species richness, mean species richness, mean density and mean biomass per trawling.

\begin{tabular}{llll}
\hline & Bay of Carteau & La Gracieuse & Total \\
\hline Number of trawlings & 31 & 26 & 57 \\
Total species richness & 37 & 30 & 47 \\
Mean species richness & $6.55(0.84)$ & $9.19(0.56)$ & $7.68(0.61)$ \\
Mean density (individuals ha $\left.{ }^{-1}\right)$ & $837(283)$ & $401(76)$ & $650(162)$ \\
Mean biomass $\left(\mathrm{g} \mathrm{ha}^{-1}\right)$ & $1874(397)$ & $3724(588)$ & $2667(402)$ \\
\hline
\end{tabular}

Confidence intervals at $\alpha=5 \%$ level are in brackets.

Table IV. Summary of two-way ANOVAs involving mean species richness, density and biomass.

\begin{tabular}{|c|c|c|c|}
\hline & \multicolumn{3}{|c|}{ Source of variation } \\
\hline & Area & Season & Area $\times$ Season \\
\hline Mean species richness & $* * *$ & $* * *$ & ns \\
\hline Mean density & $* * *$ & $*$ & $*$ \\
\hline Mean biomass & ** & ns & ns \\
\hline
\end{tabular}

Level of significance: $* * *=P<0.001, * *=P<0.01, *=P<0.05$, and ns $=P>0.05$. 


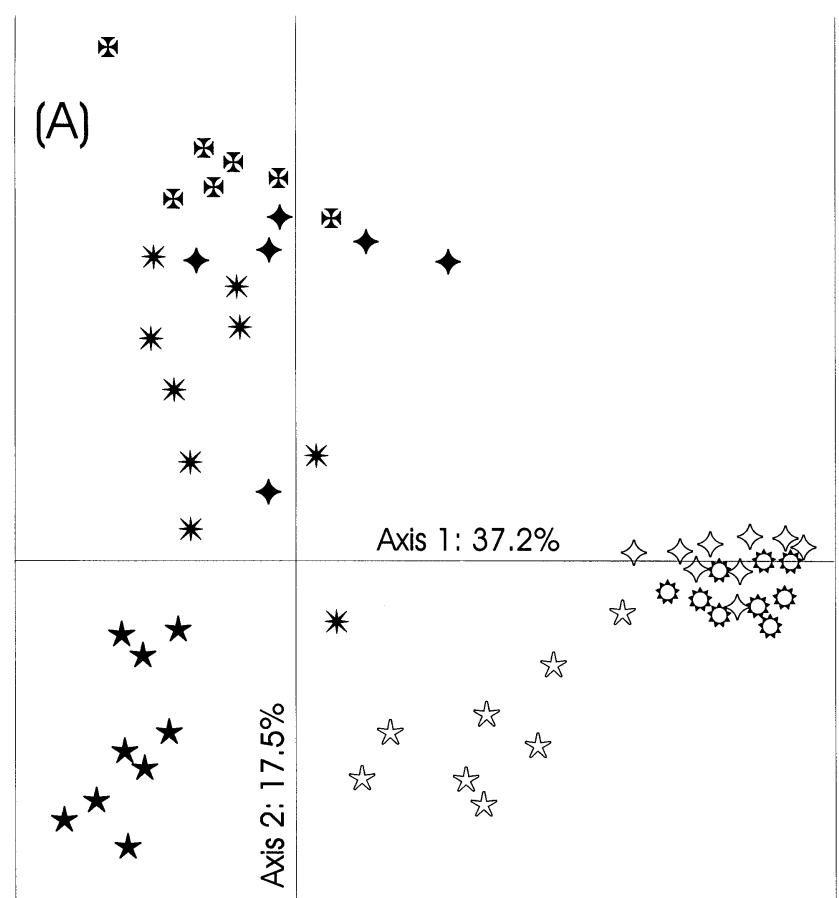

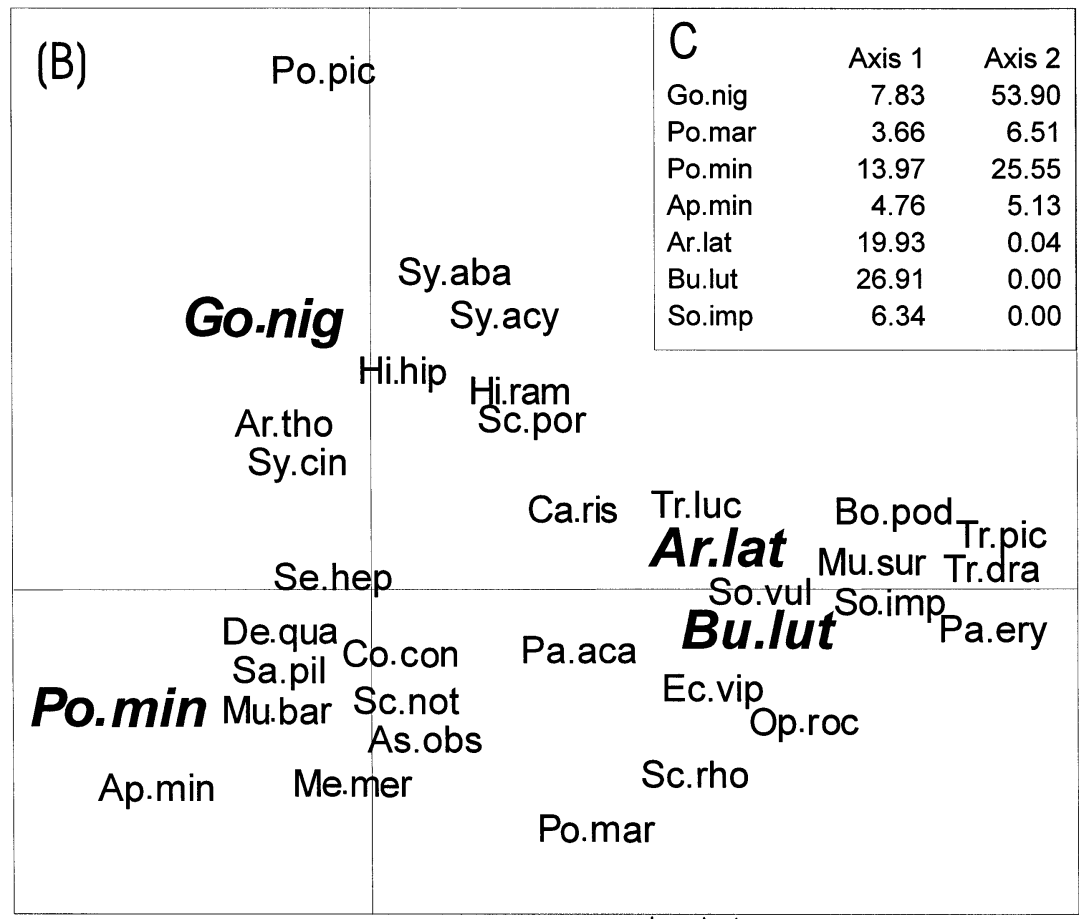

Figure 2. A. First factorial plane of the correspondence analysis monitored on the fish density data from summer 1983 to summer 1985. Significance of trawled stations: $\star$, Carteau, summer 1983; Carteau, summer 1984; $\uparrow$, Carteau, winter 1984; *, Carteau, spring 1985; $\diamond$, La Gracieuse, summer 1984; La Gracieuse, winter 1984; and La Gracieuse, summer 1985. B. Projection of species along the first factorial plane of the correspondence analysis monitored on the fish density data set (see able $V$ for correspondence between species and codes). C. Absolute contributions of species to axes one and two are expressed in percentage of inertia of each axis. Only species with absolute contribution $>5 \%$ for at least one axis are mentioned, and species with absolute contribution $>10 \%$ are mentioned in bold italics on (B).
The importance of rare species, i.e. those caught on only one occasion, was relatively high in terms of the number of species and biomass in both areas, but concerned only
2.0 to $3.0 \%$ of fish density (table $I$ ). These species represented a similar part of the assemblage in both areas, except for biomass. 
The most numerous fish species in Carteau were three gobiids, whereas two flatfish and two gobiids dominated in La Gracieuse (table - W ). Another pattern appeared when the biomass was considered, emphasising the importance of Solea solea in both Carteau (rank 2, if we consider the biomass of Conger conger as 'non-reprensentative' due to its low density), and La Gracieuse, where it was the dominant species, followed by three other flatfish, Arnoglossus laterna, Buglossidium luteum and Solea impar. In both areas, almost all fish species, particularly the most abundant ones, were carnivores, feeding mainly on benthic crustaceans, polychaetes and molluscs.

Table V. Mean density and biomass of the fish species caught at Fos.

\begin{tabular}{|c|c|c|c|c|c|}
\hline \multirow[b]{2}{*}{ Fish taxa } & \multirow[b]{2}{*}{ Code } & \multicolumn{2}{|c|}{ Density (individuals $\mathrm{ha}^{-1}$ ) } & \multicolumn{2}{|c|}{ Biomass $\left(\mathrm{g} \mathrm{ha}^{-1}\right)$} \\
\hline & & Carteau & La Gracieuse & Carteau & La Gracieuse \\
\hline \multicolumn{6}{|l|}{ Torpenididae } \\
\hline Torpedo marmorata & To.mar & $0.23(0.45)$ & - & $68.6(169.7)$ & - \\
\hline \multicolumn{6}{|l|}{ Clupaeidae } \\
\hline Sardina pilchardus & Sa.pil & $1.86(2.53)$ & - & $1.1(3.8)$ & - \\
\hline \multicolumn{6}{|l|}{ Congridae } \\
\hline Conger conger & Co.con & $1.54(1.76)$ & $0.37(0.50)$ & $225.1(330.6)$ & $151.5(271.5)$ \\
\hline \multicolumn{6}{|l|}{ Gadidae } \\
\hline Merluccius merluccius & Me.mer & $0.31(0.61)$ & $0.19(0.36)$ & $5.9(11.7)$ & $5.7(11.2)$ \\
\hline \multicolumn{6}{|l|}{ Ophiidae } \\
\hline Ophidion barbatum & Op.bar & - & $0.18(0.36)$ & - & $0.8(1.5)$ \\
\hline O. rochei & Op.roc & - & $8.12(5.28)$ & - & $170.2(122.0)$ \\
\hline \multicolumn{6}{|l|}{ Syngnathidae } \\
\hline Hippocampus hippocampus & Hi.hip & $1.24(1.15)$ & - & $6.4(6.2)$ & - \\
\hline H. ramulosus & Hi.ram & $0.93(1.82)$ & $0.55(0.61)$ & $1.8(3.5)$ & $1.6(2.2)$ \\
\hline Syngnathus abaster & Sy.aba & $1.86(2.21)$ & - & $0.8(0.9)$ & - \\
\hline S. acus & Sy.acu & $0.93(1.33)$ & - & $5.1(7.1)$ & - \\
\hline S. typhle & Sy.typ & $0.31(0.61)$ & - & $0.2(0.5)$ & - \\
\hline \multicolumn{6}{|l|}{ Scorpaenidae } \\
\hline Scorpaena notata & Sc.not & $1.24(1.15)$ & $0.19(0.36)$ & $5.0(7.8)$ & $7.8(15.3)$ \\
\hline S. porcus & Sc.por & $0.23(0.45)$ & $0.19(0.36)$ & $0.4(0.7)$ & $36.1(60.8)$ \\
\hline \multicolumn{6}{|l|}{ Triglidae } \\
\hline Aspitrigla obscura & As.obs & $5.88(4.98)$ & $1.11(1.20)$ & $19.1(24.0)$ & $61.0(67.6)$ \\
\hline Lepidotrigla cavillone & Le.cav & - & $0.19(0.36)$ & - & $0.8(1.5)$ \\
\hline Trigla lucerna & Tr.luc & $0.31(0.61)$ & $0.73(0.85)$ & $0.1(0.3)$ & $5.5(9.9)$ \\
\hline \multicolumn{6}{|l|}{ Serranidae } \\
\hline Serranus hepatus & Se.hep & $3.17(2.16)$ & $0.19(0.36)$ & $15.1(10.6)$ & $0.1(0.1)$ \\
\hline \multicolumn{6}{|l|}{ Carangidae } \\
\hline Trachurus mediterraneus & Tr.med & $0.62(1.21)$ & - & $1.9(3.8)$ & - \\
\hline T. picturatus & Tr.pic & - & $0.55(0.60)$ & - & $0.6(0.7)$ \\
\hline \multicolumn{6}{|l|}{ Mullidae } \\
\hline Mullus barbatus & Mu.bar & $0.93(1.33)$ & - & $12.8(17.5)$ & - \\
\hline M. surmulletus & Mu.sur & - & $3.51(2.63)$ & - & $8.0(7.7)$ \\
\hline \multicolumn{6}{|l|}{ Sparidae } \\
\hline Lithognathus mormyrus & Li.mor & - & $0.19(0.36)$ & - & $9.2(18.1)$ \\
\hline Pagellus acarne & Pa.aca & $0.54(0.75)$ & $1.66(1.47)$ & $3.0(4.1)$ & $1.9(1.8)$ \\
\hline P. bogaraveo & Pa.bog & - & $0.19(0.36)$ & - & $1.1(2.1)$ \\
\hline P. erythrinus & Pa.ery & - & $1.29(0.98)$ & - & $10.3(10.2)$ \\
\hline \multicolumn{6}{|l|}{ Labridae } \\
\hline Symphodus cinereus & Sy.cin & $2.09(1.86)$ & - & $29.8(32.4)$ & - \\
\hline \multicolumn{6}{|l|}{ Trachinidae } \\
\hline Echiichthys vipera & Ec.vip & - & $1.66(1.16)$ & - & $10.6(8.1)$ \\
\hline Trachinus draco & Tr.dra & - & $2.21(1.30)$ & - & $22.9(17.5)$ \\
\hline \multicolumn{6}{|l|}{ Clinidae } \\
\hline Clinitrachus argentatus & Cl.arg & $0.31(0.61)$ & - & $1.0(1.9)$ & - \\
\hline
\end{tabular}


Table V. Continued

\begin{tabular}{|c|c|c|c|c|c|}
\hline \multirow[b]{2}{*}{ Fish taxa } & \multirow[b]{2}{*}{ Code } & \multicolumn{2}{|c|}{ Density (individuals $\mathrm{ha}^{-1}$ ) } & \multicolumn{2}{|c|}{ Biomass $\left(\mathrm{g} \mathrm{ha}^{-1}\right)$} \\
\hline & & Carteau & La Gracieuse & Carteau & La Gracieuse \\
\hline \multicolumn{6}{|l|}{ Blenniidae } \\
\hline Blennius tentacularis & B1.ten & $0.31(0.61)$ & - & $2.0(3.8)$ & - \\
\hline \multicolumn{6}{|l|}{ Callionymidae } \\
\hline Callionymus risso & Ca.ris & $8.67(4.31)$ & $13.66(6.69)$ & $11.0(5.4)$ & $15.95(7.22)$ \\
\hline \multicolumn{6}{|l|}{ Gobiidae } \\
\hline Aphia minuta & Ap.min & $66.79(50.76)$ & - & $42.3(32.6)$ & - \\
\hline Deltentosteus quadrimaculatus & De.qua & $10.22(6.23)$ & - & $25.0(15.0)$ & - \\
\hline Gobius fallax & Go.fal & $1.24(2.42)$ & - & $2.8(5.4)$ & - \\
\hline G. niger & Go.nig & $322.13(106.51)$ & $3.51(2.84)$ & $738.8(245.4)$ & $14.9(12.1)$ \\
\hline Pomatoschistus marmoratus & Po.mar & $3.09(6.06)$ & $46.32(35.09)$ & $6.2(5.6)$ & $94.5(74.5)$ \\
\hline P. microps & Po.mic & $0.31(0.61)$ & - & $0.1(0.2)$ & - \\
\hline P. minutus & Po.min & $388.14(303.89)$ & $65.89(46.92)$ & $182.5(137.4)$ & $69.7(48.9)$ \\
\hline P. pictus & Po.pic & - & $0.19(0.36)$ & - & $0.1(0.2)$ \\
\hline \multicolumn{6}{|l|}{ Scophthalmidae } \\
\hline Scophthalmus rhombus & Sc.rho & - & $1.48(1.25)$ & - & $236.3(328.1)$ \\
\hline \multicolumn{6}{|l|}{ Bothidae } \\
\hline Arnoglossus laterna & Ar.lat & $23.68(8.24)$ & $89.33(30.29)$ & $93.4(35.8)$ & 337.7 (89.8) \\
\hline A. thori & Ar.tho & $1.86(1.35)$ & - & $13.3(13.5)$ & - \\
\hline Bothus podas & Bo.pod & - & $7.01(3.94)$ & - & $182.0(83.9)$ \\
\hline \multicolumn{6}{|l|}{ Pleuronectidae } \\
\hline Platichthys flesus & Pl.fle & - & $0.18(0.36)$ & - & $44.3(86.8)$ \\
\hline \multicolumn{6}{|l|}{ Soleidae } \\
\hline Buglossidium luteum & Bu.lut & $31.19(11.15)$ & $114.43(29.82)$ & $142.7(54.1)$ & $673.7(206.9)$ \\
\hline Solea impar & So.imp & - & $14.03(5.24)$ & - & $369.8(148.4)$ \\
\hline Solea solea & So.sol & $2.40(2.27)$ & $14.95(4.18)$ & $213.5(357.7)$ & $1236.0(509.1)$ \\
\hline
\end{tabular}

Code: see Ggure ; values in brackets are confidence intervals at $\alpha=5 \%$; - indicates the absence of the species.

\subsection{Seasonal fluctuations}

Mean species richness, density and biomass varied over time in both areas. Anovas showed that these fluctuations were statistically significant, except for biomass table W. However, the post hoc SNK tests showed a significant decrease of biomass in La Gracieuse $(P<0.05)$ but the decrease of $-69 \%$ (table V statistically significant $(P>0.05)$. In this area, all descrip- tors displayed a marked decrease, ranging from $-51 \%$ (species richness) to $-84 \%$ (density), between summer 1983 and spring 1985. Conversely, in La Gracieuse, significant and opposite seasonal trends appeared for mean density and biomass, with a higher density in winter, and a higher biomass in summer (table V V d ). Density and biomass figures were lower in 1985 than in 1984. Species richness constantly decreased over time, but the difference was only significant between summer 1984 and summer 1985 ( $t$-test, $P<0.05$ ).

Table VI. Mean species richness, mean density and mean biomass per season.

\begin{tabular}{|c|c|c|c|c|c|c|c|}
\hline & \multicolumn{3}{|l|}{ La Gracieuse } & \multicolumn{4}{|l|}{ Carteau } \\
\hline & S 1984 & W 1985 & S 1985 & S 1983 & W 1984 & S 1984 & Sp 1985 \\
\hline Mean species richness & $10.67(0.86)$ & $9.13(0.86)$ & $7.78(1.12)$ & $9.67(0.80)$ & $7.17(1.18)$ & $4.57(0.94)$ & $4.78(1.59)$ \\
\hline Mean density (individuals ha $^{-1}$ ) & 443 (119) & $575(171)$ & $186(17)$ & 2029 (1029) & $621(416)$ & $374(224)$ & $324(159)$ \\
\hline Mean biomass $\left(\mathrm{g} \mathrm{ha}^{-1}\right)$ & $5432(2307)$ & $2481(798)$ & 3258 (1163) & 3544 (2976) & $1534(649)$ & $1318(662)$ & $1099(946)$ \\
\hline
\end{tabular}

Confidence intervals at $\alpha=5 \%$ level are in brackets; S: summer, W: winter, Sp: spring. 
Table VII. Relative importance of juveniles of the most abundant flatfish species, for each season and area.

\begin{tabular}{|c|c|c|c|c|c|c|c|}
\hline \multirow[b]{2}{*}{ Fish species } & \multicolumn{4}{|l|}{ Carteau } & \multicolumn{3}{|c|}{ La Gracieuse } \\
\hline & S 1983 & W 1984 & S 1984 & Sp 1985 & S 1984 & W 1985 & S 1985 \\
\hline Arnoglossus laterna & 48.3 & 21.2 & $\mathrm{nc}$ & 46.1 & 75.9 & 31.7 & 30.3 \\
\hline Buglossidium luteum & 53.8 & 39.7 & 60.1 & 71.4 & 16.1 & 32.3 & 40.9 \\
\hline Solea impar & - & - & - & - & 19.1 & nc & 27.3 \\
\hline Solea solea & $\mathrm{nc}$ & $\mathrm{nc}$ & $\mathrm{nc}$ & $\mathrm{nc}$ & 21.7 & 2.9 & 3.2 \\
\hline
\end{tabular}

Values are expressed as a percentage of the species population; for each season, all trawls were pooled together; nc: not calculated ( $n<15$ individuals), - : absence of the species. S: summer, W: winter, Sp: spring.

Some species, like the flatfish Bothus podas, Buglossidium luteum, Solea impar and S. solea, decreased both in density and biomass during winter in La Gracieuse, and exhibited a seasonal density trend opposed to the overall assemblage. This pattern was mostly due to the presence of numerous juveniles during summer periods, and their scarcity in winter. Conversely, other fish like the gobiids Pomatoschistus marmoratus and P. minutus increased in density and biomass during winter, exhibiting a biomass trend opposed to the overall assemblage. Patterns were less complex in Carteau, where species generally fluctuated in accordance with the overall assemblage, with the exception of Callionymus risso, which showed an increase both in density and biomass during the study period.

For the most abundant flatfish species, juveniles were present at all seasons but their percentages among the populations were usually lower in winter than in summer or spring (table $V \mathrm{Vl})$.

\subsection{Diel variations}

Chronological clusterings did not reveal any significant diel variations in species richness, density or biomass, for either the whole assemblage or its major components (flatfish and gobiids). Diel patterns differed between years for the same season, both in Carteau and La Gracieuse (figure 3). Trends in species richness were reversed between summer 84 and summer 85 at La Gracieuse, and between summer 83 and summer 84 at Carteau.

However, diel variations appeared more clearly during summer than during winter or spring. In particular, an increase in density and biomass at sunset and a decrease before sunrise were observed in summer 84 at $\mathrm{La}$ Gracieuse and summer 83 at Carteau (figure 3 ). The most important diel changes were of three types. First, nocturnal macrocarnivorous species, like Conger conger and Ophidion rochei were only caught during and just after sunset. Second, other species, like Callionymus risso, disappeared from catches at night as they burrowed into the sediment. Third, the abundance of some species, mainly flatfish, differed between night and day. Buglossidium luteum was mainly caught during the night, whereas Arnoglossus laterna was mainly caught during the day.

\section{DISCUSSION}

\subsection{Spatial distribution}

In the Gulf of Fos, a few families dominated soft-bottom fish assemblages, particularly flatfish and Gobiidae. The importance of Gobiidae was underlined in soft-bottom fish assemblages in the Baltic Sea Thorman and Wiederholm, 1983: Thorman, 1986) and in Spain Iglesias, 1981: Ramos-Espla_and Pérez-Ruzafa, 1985) In addition to gobiids, the important role of the flatfish Platichthys flesus was also noted in the Baltic Sea Jansson et al. 1985). Similar observations have been made in other soft-bottom areas around the world Coviatt and Nixon. 1973: Walton and Barton. 1976: Warburton and Blaher. 1992: Wagner and Austin, 1999) These similarities between soft-bottom fish assemblages over the world may reflect a similarity in how soft-bottom ecosystems function. These ecosystems are based on relatively 'simple' trophic interactions, most likely represented by the following major pathways: microphytobenthos and detritus $\rightarrow$ micro- and macrofauna (small invertebrates) $\rightarrow$ carnivorous fish (flatfish, gobiids, etc.). Due to the physical conditions in the area (e.g. wave action and, 


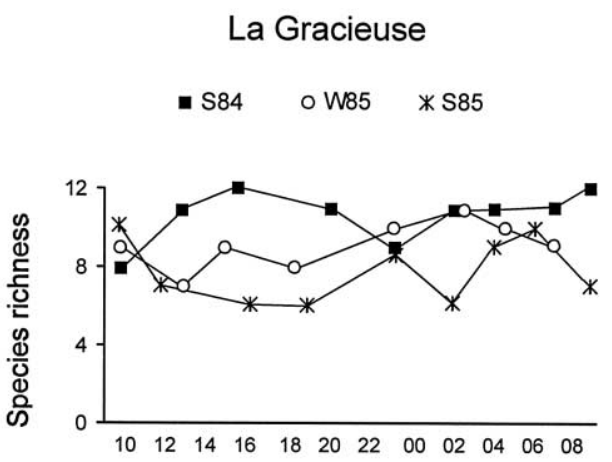

\section{Bay of Carteau}

- S83 O W83 * S84 $\bullet 85$
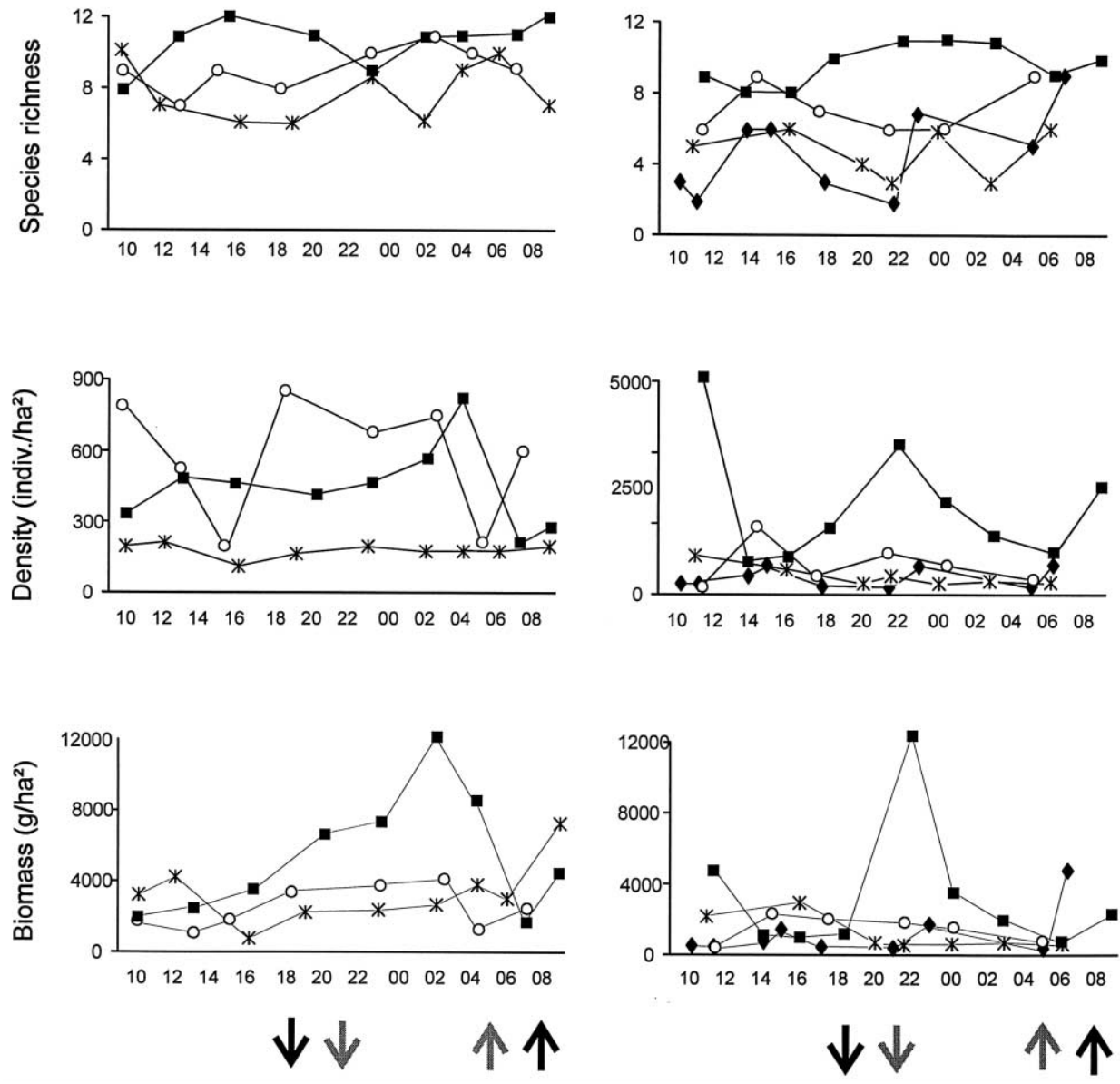

Figure 3. Diel variations of species richness, density and biomass in $\mathrm{La}$ Gracieuse and Carteau, from 1983 to 1985 . Hours of sunrise and sunset are indicated by black arrows for winter (W), and by grey arrows for summer (S), this timing being intermediate in spring $(\mathrm{P})$.

more generally, instable hydrodynamic conditions, muddy and sand-mud mixed sediment), erected macroalgae are poorly developed. This, in addition to the abundance of potential preys (polychaetes, molluscs and crustaceans) could explain the absence of herbivorous species and the large abundance of micro- and macrocarnivorous fish in the assemblage. A similar explanation was proposed for the soft-bottom communities of New Caledonia, where benthic carnivorous fish represented $75 \%$ of the total biomass Wantiez, 1994.

Differences in ichthyofauna between the inner and the outer parts of the Gulf of Fos may be linked to several factors. Differences in wave agitation created two bio- cenoses that differed in granulometric characteristics. In Carteau, the inner part of the gulf, wave agitation was lower, and muddy components largely dominated the sediment Stora and Romano. 1980) whereas in $\mathrm{La}$ Gracieuse, the outer part of the gulf, the sandy fraction dominated [Fèbvre-Chevalier. 1969). Although more diversified in the inner part of the gulf, the specific composition of invertebrate populations were quite similar in both areas, but the relative importance of invertebrate groups varied according to the biocenosis. In a decreasing order of importance in density, bivalves, crustaceans and polychaetes dominated the macrofaunal assemblages in the outer part of the gulf, whereas gastropods, holothurians, crustaceans, bivalves and poly 
chaetes characterised the inner part Stora_and_Romano 1980). Flatfish species have been shown to have quite different food preferences in the two areas of the Gulf of Fos Darnaude et al. 2001. Food resource partitioning occurred both between species and between individuals of different sizes within a flatfish species. This food resource partitioning could also occur between other fish species (Warburton and Blaber. 1992), and might then explain the patterns found: the differences in prey populations which exist between the two areas could lead to two different predator assemblages according to the respective food preferences of the fish.

\subsection{Temporal fluctuations}

Although diel patterns have rarely been studied in Mediterranean fish communities, the trend found here was opposite to those found in complex marine ecosystems like Posidonia oceanica beds Harmelin-Vivien. 1982. Erancour, 1990). These complex ecosystems offer a large number of different habitats for fish as well as invertebrates of various sizes. In such a context, high species richness is the usual response of fish communities. This most often results in an increase in the temporal partitioning by the various species in the community, thereby explaining the clearer diel patterns observed in complex systems [Harmelin-Vivien. 1982). On the shallow softbottoms of the Gulf of Fos, there is probably a strong synergy between the simple benthic structure and the high hydrological instability of the area, which could favour temporal variations with quite long cycles, like seasonal patterns, rather than with shorter cycles, like diel patterns.

During the study, a decrease in species richness, density and biomass was observed at both La Gracieuse and Carteau, without any seasonal trend for the latter area. A first possible explanation might be linked to the establishment, in 1985, of large structures for intensive mussel aquaculture in the bay of Carteau. One could suggest that fishermen increased their fishing effort before fishing was prohibited. Although this phenomenon has already been observed on some coral reefs before the establishment of marine reserves and fishing restrictions (Wantiez, personal communication), there were no similar observations or available data which could support this hypothesis in the case of the Gulf of Fos.

The area under study is subject to freshwater inputs (from de Berre Lagoon and from the Rhône River), which, in addition to the numerous factories and refineries, brought in large amounts of pollutants. Pollution generally has a strong effect on benthic communities Reish and Bellan. 1995) but there is no clear evidence to demonstrate its role in the decrease in all fish assemblage descriptors observed in the Gulf of Fos during the study period.

The observed pattern may be a reflection of temporal fluctuations under normal circumstances. River inputs also provide particular matter and nutrients that can enhance marine pelagic and benthic production. These inputs are controlled by the river flow (Cauwet, 1995. Moutin_et_al__1998) and, over a long term, it has been demonstrated that a positive correlation between the Rhône River discharge and the abundance of benthic polychaetes does exit Salen-Picardetal._1997) Over the study period, mainly due to variations in rainfall, the flow of the Rhône River strongly decreased from a mean flow rate of $2059 \mathrm{~m}^{3} \mathrm{~s}^{-1}$ in 1983 down to $1480 \mathrm{~m}^{3} \mathrm{~s}^{-1}$ in 1985 (Salen-Picard, unpublished data), i.e. a decrease of $-28.1 \%$. This obvious decrease resulted in changes in benthic invertebrate populations, especially in a decrease in the abundance of subsurface deposit-feeders (SalenPicard and Arlhac, manuscript in preparation). This might suggest that the fish assemblages of the Gulf of Fos are dependant, at least in part, on terrestrial material brought in by the Rhône River, probably in an indirect way through the trophic pathway mentioned above. As the river flow is subject to interannual variations, the observed decrease in species richness, density and biomass also suggests that fish assemblages in that zone respond to new conditions after a short time lag.

In complex ecosystems, temporal variations in fish assemblages are most often based on a regular rhythm which mainly results from deterministic processes like geomorphology and biotic interactions, although stochastic processes, like recruitment, can also influence interannual variations Harmelin-Vivien, 1982) We suggest that stochastic mechanisms play a significant role in structuring fish assemblages in simple ecosystems like the soft-bottoms of the Gulf of Fos, but the relative roles of stochastic and deterministic processes were not determined. The relationships observed between river flow and fluctuations in the fish assemblages support this idea. The shallow waters of the Gulf of Fos are used as a nursery grounds by the juveniles of various fish species, especially flatfish (Darnaude et al..2001) The pattern found might then result from interannual variations in the settlement patterns of fish, possibly linked to temporal 
changes in density of invertebrate preys, which, themselves, depend on the input of terrestrial material from the Rhône River.

\section{CONCLUSION}

Fish communities in temperate soft-bottoms are strongly distributed according to spatial factors, both at a small scale, such as in the shallow Gulf of Fos, and at a larger scale, as in the whole Gulf of Lion Gaertner et al, 1998. 1999). Similar patterns also occur in tropical areas Wantiez et al, 1996) The spatial distribution found in this work remained stable over the period studied (two years), despite seasonal and diel fluctuations, which were only noticeable for certain species. Stability in the spatial distribution of soft-bottom fish communities has been observed in various regions over several years, even in the case of commercial exploitation of fish Mahon and Smith, 1989: Harris and Poiner, 1991; Farina et al. 1997. Gaertner et al, 1998)] This suggests that fish communities in such systems are mainly structured by physical and benthic characteristics rather than by variations in recruitment and settlement processes (Wantiez et al. 1996).

Only a relatively low number of species displayed strong seasonal and/or diel variations in the Gulf of Fos, demonstrating that temporal fluctuations act more at a specific level than at a structural one. This temporal variability may be linked to species, but also to some particular stages of the fish life cycle at determined periods, like juveniles in summer, which generate slight changes in species composition, but do not significantly influence the spatial organization.

\section{Acknowledgements}

We are grateful to the crew of the RV Catherine Laurence for their help in the field, to Sheryl Mellor for her assistance with the English text, and to the anonymous reviewers for their constructive comments on the manuscript.

\section{REFERENCES}

Arculeo, M., Baino, R., Riggio, S., 1990. Caratterizzazione delle faune demersali e delle marinerie del Golfo di Castellammare (Sicilia NO) attraverso una analisi triennale degli sbarchi di pesca. Natur. Sicil. $14,57-69$.
Arculeo, M., D’Anna, G., Riggio, S., 1988. Valutazione delle risorse demersali nell'area compresa fra Capo Gallo e Capo San Vito (Sicilia nord-occidentale): risultati delle campagne condotte nel 1985. Atti Seminare Pesca Acquac., 1413-1451.

Arena, P., Bombace, G., 1970. Bionomie benthique et faune ichtyologique des fonds de l'étage circalittoral et bathyal des golfes de Castellammare (Sicile NO) et de Patti (Sicile NE). Actes Journées Ichtyol. Rome, 145-156.

Blanc, F., Leveau, M., Szekielda, K.H., 1969. Effets eutrophiques au débouché d'un grand fleuve (Grand Rhône). Mar. Biol. 3, 233-242.

Botsford, L.W., Castilla, J.C., Peterson, C.H., 1997. The management of fisheries and marine ecosystem. Science 277, 509-515.

Cauwet, G., 1995. Apports du Rhône en carbone et azote dissous et particulaire de juin 1994 à juin 1995. Septièmes rencontres de l'Agence régionale pour l'environnement Provence-Alpes-Côte d'Azur. AREPACA, Marseille, pp. 263-271.

Darnaude, A., Harmelin-Vivien, M.L., Salen-Picard, C., 2001. Food partitioning among flatfish (Pisces, Pleuronectiforms) juveniles in a Mediterranean coastal shallow sandy area. J. Mar. Biol. Ass. UK 81, 119-127.

Dulcic, J., Kraljevic, M., Grbec, B., Pallaoro, A., 1997. Composition and temporal fluctuations of inshore juvenile fish populations in the Kornati archipelago. eastern middle Adriatic. Mar. Biol. 129, 267-277.

Farina, A.C., Freire, J., Gonzales-Gurriaran, E., 1997. Demersal fish assemblages in the Galician continental shelf and upper slope (NW Spain): spatial structure and long-term changes. Est. Coast. Shelf Sci. 44, 435-454.

Fèbvre-Chevalier, C., 1969. Étude bionomique des substrats meubles dragables du golfe de Fos. Tethys 1, 421-476.

Folack, J., 1986. Variations mensuelles de la biomasse et de la production du phytoplancton d'une zone côtière d'intérêt aquicole: anse de Carteau, golfe de Fos. Ph.D. thesis. Université Aix-Marseille-2, Marseille.

Francour, P., 1990. Dynamique de l'écosystème à Posidonia oceanica dans le parc national de Port-Cros. Analyse des compartiments matte, litière, faune vagile, échinodermes et poissons. Ph.D. thesis. Université Pierre-et-Marie-Curie (Paris-6), Paris.

Frid, C.L.J., Clark, R.A., Hall, J.A., 1999. Long term changes in the benthos on a heavily fished ground off the NE coast of England. Mar. Ecol. Prog. Ser. 188, 13-20.

Fujita, T., Tadashi, I., Ishito, Y., 1995. Depth-gradient structure on the demersal fish community on the continental shelf and slope off Sendai bay, Japan. Mar. Ecol. Prog. Ser. 118, 13-23.

Gaertner, J.C., 1997. Organisation des assemblages démersaux dans le golfe du Lion: structures spatiales et stabilité temporelle. Ph.D. thesis. Université de la Méditerranée, Marseille.

Gaertner, J.C., Chessel, D., Bertrand, J., 1998. Stability of spatial structures of demersal assemblages: a multitable approach. Aquat. Living Resour. 11, 75-85.

Gaertner, J.C., Mazouni, N., Sabatier, R., Millet, B., 1999. Spatial structure and habitat associations of demersal assemblages in the Gulf of Lion: a multicompartmental approach. Mar. Biol. 135, 199-208. 
Garcia, C.B., Duarte, L.O., von Schiller, D., 1998. Demersal fish assemblages of the Gulf of Salamanca, Colombia (southern Caribbean Sea). Mar. Ecol. Prog. Ser. 174, 13-25.

Harmelin-Vivien, M.L., 1981. Description d'un petit chalut à perche pour récolter la faune vagile des herbiers de posidonies. Rap. Com. Intern. Expl. Sci. Médit. 27, 199-200.

Harmelin-Vivien, M.L., 1982. Ichtyofaune des herbiers de posidonies du Parc national de Port-Cros. I: composition et variations spatio-temporelles. Trav. Sci. Parc nat. Port-Cros 8, 69-92.

Harris, A.N., Poiner, I.R., 1991. Changes in species composition of demersal fish fauna of southeast Gulf of Carpentaria, Australia, after 20 years of fishing. Mar. Biol. 111, 503-519.

Iglesias, J., 1981. Spatial and temporal changes in the demersal fish community of the Ria de Arosa (NW Spain). Mar. Biol. 65, 199-208.

Jansson, B.O., Aneer, G., Nellbring, S., 1985. Spatial and temporal distribution of the demersal fish fauna in a Baltic archipelago as estimated by scuba census. Mar. Ecol. Prog. Ser. 23, 31-43.

Jennings, S., Kaiser, M.K., 1998. The effects of fishing on marine ecosystems. In: Blaxter, J.H.S., Southward, A.J., Tyler, P.A. (Eds.), Advances in marine biology. Academic Press, London, pp. 201-352.

Lagardère, F., Amara, R., Joassard, L., 1999. Vertical distribution and feeding activity of metamorphosing sole, Solea solea, before immigration to the Bay of Vilaine nursery (northern Bay of Biscay, France). Env. Biol. Fish. 56, 213-228.

Le Direac'h-Boursier, L., 1990. Recrutement et comportement larvaire: ichtyoplancton du golfe de Fos. Étude expérimentale du déterminisme des migrations des larves et juvéniles de sole Solea solea. Ph.D. thesis. Université Aix-Marseille-2, Marseille.

Legendre, P., Dallot, S., Legendre, L., 1985. Succession of species within a community: chronological clustering, with applications to marine and freshwater zooplancton. Amer. Nat. 125, 257-288.

Mahon, R., Smith, R.W., 1989. Demersal fish assemblages on the Scotian shelf, northwest Atlantic: spatial distribution and persistence. Can. J. Aquat. Fish. Sci. 46, 134-152.

Moutin, T., Raimbault, P., Golterman, H., Coste, B., 1998. The input of nutrients by the Rhône River into the Mediterranean Sea: recent observations and comparison with earlier data. Hydrobiologia 373, $1-10$.

Oviatt, C.A., Nixon, S.W., 1973. The demersal fish of Narragansett Bay: an analysis of community structure, distribution and abundance. Est. Coast. Shelf Sci. 1, 361-378.

Pauly, D., Christensen, V., Dalsgaard, J., Froese, R., Torres, F., 1998. Fishing down marine food webs. Science 279, 860-863.

Pipitone, C., Badalamenti, F., D’Anna, G., Patti, B., 2000. Fish biomass increase after a four-year trawl ban in the Gulf of Castellammare (NW Sicily, Mediterranean Sea). Fish. Res. 48, 23-30.

Ramos-Espla, A.A., Pérez-Ruzafa, A., 1985. Contribucion al conocimiento de la ictiofauna bentonica del Mar Menor (SE España) y su distribucion bionomica. Anales Biol. Univ. Murcia 4, 49-55.

Reina-Hervas, J.A., Serrano, P., 1987. Structural and seasonal variations of inshore fish populations in Malaga Bay, Southeastern Spain. Mar. Biol. 95, 501-508.
Reish, D.J., Bellan, G., 1995. The long term effects of municipal discharges from outfall seasewers from urban areas on the marine environment. In: Bellan-Santini, D., Bonin, G., Emig, C. (Eds.), Functioning and dynamics of natural and perturbed ecosystems. Lavoisier, Paris.

Reys, J.P., 1960. Étude de la nourriture de quelques poissons démersaux du golfe du Lion. Rec. Trav. St. Mar. Endoume Fac. Sci. Mars. 33, 463-550.

Romesburg, H.C., 1985. Exploring, confirming and randomization tests. Comput. Geosci. 11, 19-37.

Roux, R.M., Vernier, E., 1975. Évolution récente des fonds meubles de la partie occidentale du golfe de Fos. C. R. Acad. Sci. III 280, 2097-2100

Salen-Picard, C., Bellan-Santini, D., Bellan, G., Arlhac, D., Marquet, R., 1997. Changements à long terme dans une communauté benthique d'un golfe méditerranéen (golfe de Fos). Oceanol. Acta 20, 299-310.

Saville, A., 1978. Méthodes de prospection pour l'évaluation des ressources halieutiques. Doc. Tech. Pêches FAO Rome 171, 1-81.

Sokal, R.R., Rohlf, F.J., 1981. Biometry, 2d edition. Freeman Press, San Fransisco.

Stora, G., Romano, J.C., 1980. Influence de la construction et de l'exploitation d'un complexe portuaire et industriel sur la distribution et l'évolution des peuplements benthiques littoraux d'un golfe méditerranéen. Prog. Wat. Res. 12, 137-144.

Thorman, S., 1986. Physical factors affecting the abundance and species richness of fish in the shallow waters of the southern Bothnian Sea (Sweden). Est. Coast. Shelf Sci. 22, 357-369.

Thorman, S., Wiederholm, A.M., 1983. Seasonal occurrence and food resource use of an assemblage of nearshore fish species in the Bothnian Sea, Sweden. Mar. Ecol. Prog. Ser. 10, 223-229.

van der Veer, H.W., Witte, J.I., 1999. Year-class strength of plaice Pleuronectes platessa in the southern bight of the North Sea: a validation and analysis of the inverse relationship with winter seawater temperature. Mar. Ecol. Prog. Ser. 184, 245-257.

Wagner, C.M., Austin, H.M., 1999. Correspondence between environmental gradients and summer fish littoral assemblages in low salinity reaches of the Chesapeake Bay, USA. Mar. Ecol. Prog. Ser. 177, 197-212.

Walton, J.M., Bartoo, N.W., 1976. Flatfish densities determined with a diver-operated flounder sampler. J. Fish. Res. Bd. Can. 33, 2834-2836.

Wantiez, L., 1994. Réseaux trophiques de l'ichtyofaune des fonds meubles lagonaires de Nouvelle-Calédonie. C.R. Acad. Sci. III 317, $847-856$.

Wantiez, L., Harmelin-Vivien, M.L., Kulbicki, M., 1996. Spatial and temporal variation in a soft-bottom fish assemblage in St-Vincent Bay, New Caledonia. Mar. Biol. 125, 801-812.

Warburton, W., Blaber, S.J.M., 1992. Patterns of recruitment and resource use in a shallow-water fish assemblage in Moreton Bay, Queensland. Mar. Ecol. Prog. Ser. 90, 113-126. 